\title{
Usage and Impacts of Technologies and Management Practices in Ethiopian Smallholder Maize Production
}

\author{
Banchayehu Tessema Assefa ${ }^{1,2, *}$, Jordan Chamberlin ${ }^{3}$, Martin K. van Ittersum ${ }^{1}$ and Pytrik Reidsma ${ }^{1}$ \\ 1 Plant Production Systems, Wageningen University, 6700 AK Wageningen, The Netherlands; \\ martin.vanittersum@wur.nl (M.K.v.I.); pytrik.reidsma@wur.nl (P.R.) \\ 2 International Maize and Wheat Improvement Center (CIMMYT), Addis Ababa P.O. Box 5689, Ethiopia \\ 3 International Maize and Wheat Improvement Center (CIMMYT), Nairobi P.O. Box 1041-00621, Kenya; \\ Jordan.Chamberlin@fao.org \\ * Correspondence: banchayehu.assefa@wur.nl or banchtes@gmail.com
}

Citation: Assefa, B.T.; Chamberlin, J.; van Ittersum, M.K.; Reidsma, P. Usage and Impacts of Technologies and Management Practices in Ethiopian Smallholder Maize Production. Agriculture 2021, 11, 938. https://doi.org/10.3390/ agriculture11100938

Academic Editor: Emanuele Radicetti

Received: 6 August 2021

Accepted: 22 September 2021

Published: 28 September 2021

Publisher's Note: MDPI stays neutral with regard to jurisdictional claims in published maps and institutional affiliations.

Copyright: (c) 2021 by the authors. Licensee MDPI, Basel, Switzerland. This article is an open access article distributed under the terms and conditions of the Creative Commons Attribution (CC BY) license (https:// creativecommons.org/licenses/by/ $4.0 /)$.

\begin{abstract}
Maize yields can be improved through many individual technologies and management practices, but the full realization of potential benefits is generally understood to require integrated use of complementary practices. We employed two years of survey data and alternative econometric models to better understand the use of individual and bundled packages of technologies and management practices in Ethiopian maize production, i.e., fertilizers, improved varieties, herbicides, pesticides, manure, intercropping, erosion control and crop rotation (the last three labeled integrated management). Although fertilizer and improved varieties were used on $85 \%$ of maize fields, with average yields of 3.4 ton/ha, large yield gaps remain. Complementary management practices improved these yields by as much as $22 \%$, although in variable ways. Integrated management contributed to maize yield only when combined with crop protection (herbicides and/or pesticides). Combining manure with fertilizer and improved variety decreased maize yields, possibly due to manure quality and less inorganic fertilizer used on fields that received manure. Packages including crop protection increased labor productivity by $16-70 \%$, while using integrated management decreased labor productivity by almost half. In summary, the combination of management practices did not automatically lead to increased yields, partly related to the conditions under which practices were applied, indicating the need for site-specific research and recommendations for sustainable intensification.
\end{abstract}

Keywords: crop management; sustainable intensification; maize yield; labor productivity

\section{Introduction}

Understanding the low and variable crop yields of smallholder farmers has been a central research and policy priority to address food security in sub-Saharan Africa (SSA). Sustainable intensification has been the dominant agricultural development pathway advocated for responding to the growing food demand, particularly in the context of increasingly scarce agricultural land [1]. Although the components of an operational definition of sustainable intensification are sometimes debated, increasing the productivity of existing agricultural land while minimizing potential environmental impacts has been its major focus. In realizing sustainable intensification, modern input use (e.g., inorganic fertilizer, improved crop varieties) and integrated farm management have been given considerable attention in previous studies [2].

Studies of smallholder production technologies have increasingly recognized that technologies and management practices are better evaluated as packages, i.e., bundles of production decisions, rather than as single components, given their interactions in productivity outcomes [2-9]. Furthermore, management practices that affect maize yields may have differing effects on other outcomes such as household income [7,10-12] and labor productivity $[10,12]$. Consequently, farmers may not use technologies due to opportunity costs of labor and low or uncertain expected economic returns [12-15]. 
In Ethiopia, fertilizer and improved varieties are used by a higher proportion of maize producers than elsewhere in SSA, which has been linked to maize yield gains observed in Ethiopia in recent years [16-19]. For example, in 2017 and 2018, 89\% of maize fields were fertilized in the main maize growing areas of Ethiopia [20]. However, yield response to fertilizer is known to be highly variable and depends on other inputs and management factors [17].

In this paper, we extend previous studies and aim to provide an improved understanding of the selection of technologies and management practices prevailing in Ethiopian maize production that increase and protect maize yield as well as improve soil fertility. We contribute to the literature in three ways. First, we considered the joint use of a relatively large set of management practices. The classification and conceptualization of technologies and management practices have not been standardized in the literature, and hence have been addressed in different manners. Fertilizer and improved variety, either in isolation or in combination, are the technologies that have been most studied [21,22]. Soil and water conservation practices and conservation agriculture-particularly intercropping, crop rotation, and minimum tillage-have also received considerable attention [23-25]. Other studies have documented the effects of selected combinations of technologies and management practices mentioned above $[7,9,12,26-32]$. Here, we extend the existing literature by analyzing the (separate and combined) use of inorganic fertilizer, improved maize variety, pesticide, herbicide, manure, intercropping, erosion control, and crop rotation. This contrasts with much of the empirical literature which has focused more selectively on individual practices or a limited number of complementary practices. Secondly, we examined the factors that condition the decision to use individual practices as well as combinations of management practices. Better understanding these conditioning factors may help to develop interventions and policies for improving agricultural productivity. Finally, in recognition of the fact that farmers may have objectives other than yield and profit maximization which influence management decisions, we assessed how alternative practices relate to labor productivity.

\section{Materials and Methods}

\subsection{Data}

The data originate from a comprehensive household survey undertaken during the main harvest periods of 2017 and 2018 in the main maize growing areas of Ethiopia. We included five administrative zones from the Amhara and Oromia regions of Ethiopia. Sample households were selected using a spatial sampling frame. Four sampling grids of $10 \times 10 \mathrm{~km}$ were randomly generated within the major maize growing areas of Ethiopia: Jimma, Bako (West Shoa and East Wollega zones), East Shoa, and West Gojjam. Within these sampling grids, an average of eight $1 \mathrm{~km}^{2}$ grid cells were randomly selected. Finally, five to six households were selected from each sampled grid cell on the basis of the proximity of plots to the centroid of the sampled grid cell. This gave a total sample of 740 households. Data were collected on field-level (biophysical characteristics, agronomic practices, input use, and production), household-level (demographic composition, asset ownership), and community-level variables (distance to services, prices). We collected labor data on individual crop management activities (land preparation, planting, fertilizing, and weeding for each field in order to minimize potential errors that could be introduced in recalling aggregated labor use. (We did not collect labor data for pesticide and herbicide applications. However, the labor requirements of these practices is relatively minor for the field sizes in our sample.) We also asked for the source (family or hired), age (adult or children), and gender of labor inputs. To address outliers, we excluded 12 households and 252 maize fields that fell within the top and bottom one percent of values for variables of interest. The final sample comprised 3914 maize fields for the individual management practices and 3341 maize fields for the management packages. 


\subsection{Description of Variables}

\subsubsection{Overview of Technologies and Management Practices}

Technologies and management practices that have been used by maize growers to improve maize yield were investigated following previous studies in Ethiopia $[3,12,30,31,33]$. The individual management practices were the use of fertilizer, maize variety, pesticide, herbicide, manure, intercropping, erosion control, and crop rotation (Table 1). Fertilizer and improved variety are yield-increasing practices with yield effects in the same season; pesticide and herbicides are crop protection practices that can influence yield in the same season applied; manure, intercropping, erosion control, and crop rotation are related to improving yield and soil fertility in the same season and/or in subsequent seasons. We hypothesize that using the technologies and management practices individually or in combination affects maize yield.

Table 1. Frequency of using individual management practices on sample maize fields ( $\mathrm{n}=3914)$.

\begin{tabular}{ccc}
\hline No & Management Practice & Frequency \\
\hline 1 & Fertilizer $(1=$ yes $)$ & $90 \%$ \\
2 & Improved variety $(1=$ yes $)$ & $91 \%$ \\
3 & Pesticide $(1=$ yes $)$ & $6 \%$ \\
4 & Herbicide $(1=$ yes $)$ & $33 \%$ \\
5 & Manure $(1=$ yes $)$ & $24 \%$ \\
6 & Intercropping $(1=$ yes $)$ & $5 \%$ \\
7 & Erosion control $(1=$ yes $)$ & $17 \%$ \\
8 & Crop rotation $(1=$ yes $)$ & $39 \%$ \\
\hline
\end{tabular}

Fertilizer and improved maize varieties were used in combination on $85 \%$ of the maize fields in our sample. Hence, next, we considered the sub-sample of maize fields that had used both fertilizer and improved maize variety and investigated what determines the usage of crop protection (herbicide and/or pesticide), manure, and integrated management (intercropping and/or erosion control and/or crop rotation) in addition to fertilizer and improved variety. This resulted in eight sets of management practices (Table 2). Of the management packages, fertilizer, improved variety, and integrated management combined (Mgt3), were used in the highest share of the maize fields (26\%) followed by using only fertilizer and improved variety $(21 \%$; Mgt1). The management package least applied was the combination of all management practices (Mgt8).

Table 2. Management packages analyzed.

\begin{tabular}{|c|c|c|c|c|c|}
\hline $\begin{array}{l}\text { Management } \\
\text { Packages }\end{array}$ & $\begin{array}{c}\text { Fertilizer }+ \\
\text { Improved Variety }\end{array}$ & $\begin{array}{c}\text { Crop } \\
\text { Protection (Pesticide } \\
\text { and/or Herbicide) }\end{array}$ & Manure & $\begin{array}{l}\text { Integrated } \\
\text { Management (Intercropping and/or } \\
\text { Erosion Control and/or Crop Rotation) }\end{array}$ & $\begin{array}{c}\text { Frequency } \\
(\%)\end{array}$ \\
\hline Mgt1 & $\sqrt{ }$ & & & & $710(21.2)$ \\
\hline Mgt2 & $\sqrt{ }$ & & $\sqrt{ }$ & & $266(7.9)$ \\
\hline Mgt3 & $\sqrt{ }$ & & & $\sqrt{ }$ & $864(25.8)$ \\
\hline Mgt4 & $\sqrt{ }$ & & $\sqrt{ }$ & $\sqrt{ }$ & $167(5.0)$ \\
\hline Mgt5 & $\sqrt{ }$ & $\sqrt{ }$ & & & $532(15.9)$ \\
\hline Mgt6 & $\sqrt{ }$ & $\sqrt{ }$ & $\sqrt{ }$ & & $113(3.3)$ \\
\hline Mgt7 & $\sqrt{ }$ & $\sqrt{ }$ & & $\sqrt{ }$ & 586 (17.5) \\
\hline Mgt8 & $\sqrt{ }$ & $\sqrt{ }$ & $\sqrt{ }$ & $\sqrt{ }$ & $103(3.1)$ \\
\hline \multicolumn{5}{|c|}{ Total } & $3341(100 \%)$ \\
\hline
\end{tabular}




\subsubsection{Drivers of Technologies/Practices}

The factors that determine the use of management practices are provided in Table 3. The selection of the factors was informed by economic theory and the large body of empirical literature on technology adoption in SSA $[5,7,11,12,30,31,34]$.

Table 3. Description and summary statistics of the explanatory variables.

\begin{tabular}{|c|c|c|}
\hline Variable & Description & $\begin{array}{c}\text { Mean } \\
\text { (Std.Dev.) }\end{array}$ \\
\hline \multicolumn{3}{|l|}{ Field level } \\
\hline Ownership of land & Ownership status of maize field ( 1 = owned $)$ & 0.83 \\
\hline Field size & Self-reported field size (ha) & $0.4(0.3)$ \\
\hline Distance from home & Walking time in minutes from homestead to field & $8.5(10.6)$ \\
\hline Number of years acquired & Number of years since the field was acquired & $13.8(5.2)$ \\
\hline \multicolumn{3}{|l|}{ Household characteristics } \\
\hline Age & Age of household head (years) & $45.5(11.9)$ \\
\hline Gender & Sex of the household head ( $1=$ if male $)$ & 0.94 \\
\hline Education & Education of household head (years) & $3.2(3.8)$ \\
\hline Number of adults & Number of adults in the household & $3.5(1.4)$ \\
\hline Asset value & Total asset value (1000 Birr) & $6.1(8.2)$ \\
\hline Livestock number & Total number of livestock units (TLU) owned by the household & $4.8(3.1)$ \\
\hline Number of fields & Total number of fields cultivated by the household in the survey year & $7.3(2.8)$ \\
\hline \multicolumn{3}{|l|}{ Community characteristics } \\
\hline Total rainfall in the previous main season & Total rainfall of growing season of previous year $(\mathrm{mm})$ & $1027(298)$ \\
\hline $\begin{array}{l}\text { Rainfall variability in the previous } \\
\text { main season }\end{array}$ & $\begin{array}{l}\text { Coefficient of variation of rainfall in dekads of days in the previous } \\
\text { main production season }(\%)\end{array}$ & $52(11)$ \\
\hline Extension visits & Number of extension visits during the year & $1(1.3)$ \\
\hline Access to market & Walking minutes to the nearest marketplace for farm produce & $67(46.1)$ \\
\hline
\end{tabular}

\subsubsection{Definition of Outcome Variables}

While acknowledging that farmers use technologies and management practices depending on their objectives and constraints, we related management packages to yield and labor productivity to evaluate how the management practices are related to these outcomes.

- Maize productivity

We measure maize productivity as the ton of grain harvested per ha. We hypothesized that implementing all the management practices (Mgt8) gives the highest maize productivity.

- Labor productivity

Labor productivity ( $\mathrm{kg}$ of maize/person day) is measured by dividing yield ( $\mathrm{kg} / \mathrm{ha}$ ) by total labor (person days/ha) used. Total labor includes labor used for land preparation, planting, fertilizing, and weeding, with both family and hired labor. We assumed that women and men contribute equally but adjusted child labor using 0.5 as a factor. Crop protection practices (herbicide and pesticide applications) are generally understood to reduce the labor requirements of managing weeds and pests, compared with manual or mechanical methods $[32,35]$. We hypothesized that the management package that includes fertilizer, improved variety, and crop protection (Mgt5) would give the highest labor productivity.

\subsection{Estimation}

We implemented three different econometric models to address the research objectives. A multivariate probit model was used to investigate the choice of individual technologies and management practices. The factors that determine the choice of package of technologies and management practices were addressed using a multinomial logit model. Finally, a multinomial endogenous treatment effects model was employed to relate packages of management practices to outcome variables (yield and labor productivity). 


\subsubsection{Multivariate Probit Model}

Decisions to adopt individual agricultural technologies are potentially interrelated. Univariate probit regression does not capture those interdependencies and estimates will be inefficient compared to a model that accounts for correlation in the error terms [36]. A multivariate probit model helps to model the effect of explanatory factors on each technology and management practice as well as to capture interdependencies among technologies by allowing for correlation between the error terms of equations for different management practices $[8,29,34]$. Hence, we used multivariate probit model under the expected utility framework to evaluate factors that drive farmers' decisions to use management practices. In the context of technology usage, farmers decide to use a new technology if the expected utility from using it outweighs expected utility from the existing technology [37].

Mathematically,

$$
\begin{gathered}
D_{h, i, j}=1 \text { if } D_{h, i, j}^{*}>0 \text { and } 0 \text { if } D_{h, i, j}^{*}<0 \\
D_{h, i, j}^{*}=X_{h, i, j}^{\prime} \alpha+\beta \bar{X}_{j i}+u_{h, i, j}
\end{gathered}
$$

where $D^{*}$ is a latent variable representing household $h$ decision to use a management practice $j$ on maize field $i ; X_{h, i, j}$ represents a vector of variables explaining the decision of using practices (Table 3); $\alpha$ and $\beta$ are the vector of parameters and $u_{h, i, j}$ is an error term.

Estimating the pooled sample directly can give rise to inconsistent estimates if there is unobserved time-invariant heterogeneity that is correlated with the outcome of interest. To address this, we implemented the Mundlak-Chamberlain (MC) device, also referred to as the correlated random effects framework [36]. The approach is implemented by adding the time averages of time-varying explanatory variables $(\bar{X})$ as regressors, under the assumption that unobserved time-invariant characteristics of the household are correlated with the time-averages of observed covariates. Unlike a fixed-effects approach to deal with this type of endogeneity concern, the MC device has the advantage of retaining time-constant regressors of interest (such as distance to markets) in the model.

\subsubsection{Multinomial Logit Model}

In contrast to the multivariate probit framework which models binary responses in a multivariate setting, a multinomial logit model is appropriate when a nominal outcome has more than two categories [36]. In our case, we are interested in eight alternative groups of management packages (Table 2), which makes a multinomial logit model appropriate. Let us assume that a household $h$ has a set of technology and management packages $m$ to choose from $(m=1, \ldots, \mathrm{k})$ to use on maize field $i$. Household $h$ will adopt a technology set $m$ on field $i$ if the utility derived from adopting $m$ is greater than an alternative technology.

In the multinomial logit model, the probability of choosing $m$ from $k$ alternatives by household $h$ is specified as [36]:

$$
P_{h k}=\operatorname{Pr}(m=k \mid X)=\frac{\exp \left(X \beta_{k}\right)}{\left[1+\sum_{m=1}^{K} \exp \left(X \beta_{k}\right)\right]}, \mathrm{k}=1, \ldots, \mathrm{K},
$$

where $X$ represents a vector of variables (as described in Table 3) that influence the decision of household $h$ to use technology package $m$ on field $i$. The MC device is also used to address potential endogeneity issues, as detailed in Section 2.3.1.

\subsubsection{Multinomial Endogenous Treatment Effects Model}

Farmers may self-select themselves to a given management practice depending on their ability or access to information. In addition, some technologies may also be targeted at a certain group of farmers, indicating that technology use may not be exogenous $[5,11,38]$. Ignoring such concerns may be misleading as differences in outcome variables (maize yield and labor productivity) could arise from differences in unobserved characteristics, such as management abilities and skills in communications [11] and estimation results will 
be inconsistent. For example, farmers that have better managerial abilities may strictly follow crop calendars and plant their maize on time. This could affect maize yield, and if we omit such information the impact of the management packages on maize yield could be overstated. We address this issue by applying a multinomial endogenous treatment effects (METE) model, which was proposed by Deb and Trivedi [39] and later applied in empirical studies $[11,38]$. METE allows us to correct for self-selection while also allowing interdependence of decisions about using different management packages.

Our specification follows Deb and Trivedi [39]. METE involves two stages. In the first stage, household $h$ will choose among the eight management packages $m$. Let us assume that $E V_{h m}^{*}$ represents the indirect utility that would be attained if treatment $m$ is selected, $m=1,2, \ldots, \mathrm{m}$

$$
E V_{h m}^{*}=z_{h}^{\prime} \alpha_{m}+\sum_{k=1}^{m} \delta_{m k} l_{h k}+\eta_{h m}
$$

where $z_{h}$ are exogenous covariates with parameters $\alpha_{m}$ and an independently and an identically distributed error term $\eta_{h m}$. The latent variables $l_{h k}$ comprise unobserved characteristics that affect both treatment choice and outcome of household $h$ and they are assumed to be independent of $\eta_{h m}$. Furthermore, $m=1$ represents the control group, for which $E V_{m 1}^{*}=0$. We do not observe $E V_{h m}^{*}$ directly but we observe a vector of binary indicators, $d_{h}=\left(d_{h 1}, d_{h 2}, \ldots, d_{h m}\right)$ indicating if a household has used one of the management packages. Similarly, let us denote $l_{h}=\left(l_{h 1}, l_{h 2}, \ldots, l_{h m}\right)$. Then, the probability of treatment can be specified as:

$$
\operatorname{Pr}\left(d_{h m}=1 \mid z_{h}, l_{h m}\right)=g\left(z_{h}^{\prime} \alpha_{m}+\delta_{m} l_{h m}\right), m=1,2, \ldots, 8
$$

We follow Deb and Trivedi [39] and assume that $g$ has a mixed multinomial logit structure defined as:

$$
\operatorname{Pr}\left(d_{h m}=1 \mid z_{h}, l_{h m}\right)=\frac{\exp \left(z_{h}^{\prime} \alpha_{m}+\delta_{m} l_{h m}\right)}{1+\sum_{k=1}^{8} \exp \left(z_{h}^{\prime} \alpha_{k}+\delta_{k} l_{h k}\right)}
$$

Next, in the second stage, the impact of the management packages on the outcome variables (maize yield and labor productivity) is modeled as follows:

$$
\mathrm{E}\left(y_{h, f} \mid d_{h}, x_{h}, l_{h}\right)=x_{h}^{\prime} \beta+\sum_{m=1}^{8} \gamma_{m} d_{h m}+\sum_{m=1}^{8} \lambda_{m} l_{h m}
$$

where $y_{h, f}$ is maize yield or labor productivity of field $f$ of household $h, x_{h}$ is a vector of exogenous variables and $\beta$ is the associated parameter vector. Parameter $\gamma_{m}$ captures treatment effects of the management packages $(m=2, \ldots, 8)$ compared to the control group $(m=1)$. The outcome equation is also a function of the latent variables $l_{h m}$ that capture unobserved characteristics which can also affect treatment selection. A positive (negative) factor-loading parameter, $\lambda_{m}$, indicates a positive (negative) correlation between treatment and outcome through unobserved characteristics.

Even though the model is identified when similar variables are included in the treatment and outcome equations, [39] recommend identification via exclusion restrictions by including some variables in the treatment equation that do not enter the outcome equation. Here we used lagged rainfall, lagged rainfall variability, distance to main market, and distance to extension services as instruments for the outcome equations (maize yield and labor productivity). We argue that these factors are likely to affect technology choice but unlikely to affect the outcome variables directly, given the other explanatory factors controlled for in the model.

Finally, we also include the MC device to address potential endogeneity issues in this model, as explained in Section 2.3.1. 


\section{Results and Discussion}

In this section, we first provide descriptive results of the survey. Next, we present and discuss the analysis behind the use of individual practices and of the combined use of practices in packages. Finally, we try to distill the key effects of management packages on yield and labor productivity.

\subsection{Descriptive Results}

Looking at individual practices, fertilizer and improved maize varieties were the most widely used management practices on sampled maize fields (Table 1). Use of pesticide and intercropping was relatively limited and practiced on ca. $5 \%$ of the sampled maize fields. Herbicide was applied on one-third of the maize fields, and manure on a quarter of the maize fields. The likelihood ratio test (prob $>\chi^{2}=0.0000$ ) rejected the null hypothesis of independence of alternative management practices. The pairwise correlation coefficients also indicated this, although to different extents (Table 4). For example, fertilizer use was positively correlated with the use of an improved variety, pesticide, herbicide, intercropping, and crop rotation, with the strongest correlation occurring between fertilizer and improved maize variety (i.e., 0.55). However, fertilizer was negatively correlated with manure use indicating that farmers, on average, use manure and fertilizer as substitutes rather than complements. Similar results were documented in studies on Ethiopian maize production $[3,7,30,40]$.

Table 4. Correlation coefficient estimates between equation error terms from the multivariate probit model.

\begin{tabular}{|c|c|c|c|c|c|c|c|}
\hline & Fertilizer & $\begin{array}{c}\text { Improved } \\
\text { Maize Variety }\end{array}$ & Manure & Pesticide & Herbicide & Erosion Control & Intercropping \\
\hline Maize variety & $0.550 * * *$ & & & & & & \\
\hline Manure & $-0.374^{* * *}$ & $-0.156^{* * *}$ & & & & & \\
\hline Pesticide & $0.135 * *$ & 0.076 & 0.018 & & & & \\
\hline Herbicide & $0.179 * * *$ & $0.118^{* * *}$ & $-0.143^{* * *}$ & 0.073 & & & \\
\hline Erosion control & $0.085^{* *}$ & $0.119^{* * *}$ & 0.014 & $0.128^{* *}$ & $0.110^{* * *}$ & & \\
\hline Intercropping & $0.105 *$ & $-0.204^{* * *}$ & -0.077 & $0.130 *$ & $-0.256^{* * *}$ & 0.087 & \\
\hline Crop rotation & $0.130 * * *$ & 0.06 & $-0.097^{* * *}$ & 0.055 & -0.046 & $0.071 * *$ & $0.221^{* * *}$ \\
\hline
\end{tabular}

Note: All variables are binary indicators. ${ }^{*} p<0.10,{ }^{* *} p<0.05,{ }^{* * *} p<0.01$.

\subsection{Explaining the Use of Individual Management Practices}

Multivariate probit model estimation results were used to explain the effects of field, household, and community level characteristics on the use of individual management practices (Table 5).

Table 5. Multivariate probit estimates of individual management practices.

\begin{tabular}{ccccccccc}
\hline & Fertilizer & $\begin{array}{c}\text { Improved } \\
\text { Maize Variety }\end{array}$ & Manure & Pesticide & Herbicide & $\begin{array}{c}\text { Erosion } \\
\text { Control }\end{array}$ & Intercropping $\begin{array}{c}\text { Crop } \\
\text { Rotation }\end{array}$ \\
\hline \multicolumn{7}{c}{ Field Characteristics } \\
\hline Ownership of land & -0.284 & 0.180 & $0.557^{* * *}$ & 0.221 & -0.107 & -0.104 & 0.232 & -0.088 \\
$(1=$ owned) & $(0.197)$ & $(0.157)$ & $(0.145)$ & $(0.136)$ & $(0.092)$ & $(0.104)$ & $(0.151)$ & $(0.105)$ \\
Field size (log) & $1.547^{* * *}$ & $1.728^{* * *}$ & $-0.606^{* * *}$ & 0.311 & $1.341^{* * *}$ & $0.534^{* * *}$ & 0.060 & $-0.300^{*}$ \\
Distance from & $(0.234)$ & $(0.279)$ & $(0.208)$ & $(0.199)$ & $(0.163)$ & $(0.183)$ & $(0.290)$ & $(0.178)$ \\
home (log) & $0.374^{* * *}$ & $0.317^{* * *}$ & $-0.672^{* * *}$ & $0.083^{* *}$ & 0.001 & -0.005 & $-0.083^{*}$ & $0.188^{* * *}$ \\
Number of years & $(0.042)$ & $(0.042)$ & $(0.035)$ & $(0.040)$ & $(0.029)$ & $(0.027)$ & $(0.047)$ & $(0.025)$ \\
acquired (log) & 0.018 & -0.003 & $0.194^{*}$ & -0.149 & 0.010 & $0.167^{* *}$ & $-0.241^{* *}$ & $-0.157^{* *}$ \\
\hline
\end{tabular}


Table 5. Cont

\begin{tabular}{|c|c|c|c|c|c|c|c|c|}
\hline & Fertilizer & $\begin{array}{c}\text { Improved } \\
\text { Maize Variety }\end{array}$ & Manure & Pesticide & Herbicide & $\begin{array}{l}\text { Erosion } \\
\text { Control }\end{array}$ & Intercropping & $\begin{array}{c}\text { Crop } \\
\text { Rotation }\end{array}$ \\
\hline \multicolumn{9}{|c|}{ Household Characteristics } \\
\hline Age of head (log) & $\begin{array}{c}0.130 \\
(0.207)\end{array}$ & $\begin{array}{l}-0.325 \\
(0.224)\end{array}$ & $\begin{array}{l}-0.106 \\
(0.161)\end{array}$ & $\begin{array}{c}0.068 \\
(0.249)\end{array}$ & $\begin{array}{l}-0.044 \\
(0.214)\end{array}$ & $\begin{array}{c}0.257 \\
(0.180)\end{array}$ & $\begin{array}{l}-0.404 \\
(0.430)\end{array}$ & $\begin{array}{c}0.018 \\
(0.114)\end{array}$ \\
\hline $\begin{array}{c}\text { Gender of head } \\
\quad(1=\text { Male })\end{array}$ & $\begin{array}{l}-0.155 \\
(0.177)\end{array}$ & $\begin{array}{l}-0.090 \\
(0.177)\end{array}$ & $\begin{array}{c}0.064 \\
(0.134)\end{array}$ & $\begin{array}{c}0.292 \\
(0.225)\end{array}$ & $\begin{array}{l}-0.299 * \\
(0.167)\end{array}$ & $\begin{array}{l}-0.072 \\
(0.173)\end{array}$ & $\begin{array}{c}0.033 \\
(0.208)\end{array}$ & $\begin{array}{l}-0.029 \\
(0.114)\end{array}$ \\
\hline $\begin{array}{c}\text { Education of } \\
\text { head (log) }\end{array}$ & $\begin{array}{c}0.057 \\
(0.053)\end{array}$ & $\begin{array}{l}0.185^{* * *} \\
(0.060)\end{array}$ & $\begin{array}{l}-0.017 \\
(0.041)\end{array}$ & $\begin{array}{l}-0.135^{* *} \\
(0.062)\end{array}$ & $\begin{array}{c}0.083 \\
(0.051)\end{array}$ & $\begin{array}{l}0.111^{* *} \\
(0.046)\end{array}$ & $\begin{array}{l}-0.182 * * \\
(0.079)\end{array}$ & $\begin{array}{l}-0.063 \text { ** } \\
(0.031)\end{array}$ \\
\hline Adults $(\log )$ & $\begin{array}{l}-0.061 \\
(0.162)\end{array}$ & $\begin{array}{l}-0.346^{*} \\
(0.189)\end{array}$ & $\begin{array}{l}0.221 * \\
(0.117)\end{array}$ & $\begin{array}{l}-0.009 \\
(0.204)\end{array}$ & $\begin{array}{l}-0.222 \\
(0.148)\end{array}$ & $\begin{array}{l}-0.060 \\
(0.144)\end{array}$ & $\begin{array}{l}0.706^{* * *} \\
(0.268)\end{array}$ & $\begin{array}{l}0.178 * \\
(0.094)\end{array}$ \\
\hline Asset value (log) & $\begin{array}{c}0.058 \\
(0.060)\end{array}$ & $\begin{array}{l}0.181^{* *} \\
(0.071)\end{array}$ & $\begin{array}{l}0.122^{* * *} \\
(0.045)\end{array}$ & $\begin{array}{c}0.018 \\
(0.074)\end{array}$ & $\begin{array}{l}-0.014 \\
(0.056)\end{array}$ & $\begin{array}{l}-0.061 \\
(0.054)\end{array}$ & $\begin{array}{l}-0.017 \\
(0.086)\end{array}$ & $\begin{array}{c}0.048 \\
(0.038)\end{array}$ \\
\hline Livestock (log) & $\begin{array}{l}-0.043 \\
(0.124)\end{array}$ & $\begin{array}{c}0.155 \\
(0.159)\end{array}$ & $\begin{array}{l}0.259^{* *} \\
(0.114)\end{array}$ & $\begin{array}{c}0.013 \\
(0.224)\end{array}$ & $\begin{array}{c}0.091 \\
(0.138)\end{array}$ & $\begin{array}{c}0.146 \\
(0.145)\end{array}$ & $\begin{array}{c}0.190 \\
(0.194)\end{array}$ & $\begin{array}{l}-0.046 \\
(0.085)\end{array}$ \\
\hline $\begin{array}{l}\text { Number of } \\
\text { plots (log) }\end{array}$ & $\begin{array}{c}0.005 \\
(0.160)\end{array}$ & $\begin{array}{l}-0.724^{* * *} \\
(0.195)\end{array}$ & $\begin{array}{l}-0.463 \\
* * * \\
(0.112)\end{array}$ & $\begin{array}{c}0.194 \\
(0.194)\end{array}$ & $\begin{array}{c}0.107 \\
(0.135)\end{array}$ & $\begin{array}{c}0.166 \\
(0.142)\end{array}$ & $\begin{array}{c}0.131 \\
(0.200)\end{array}$ & $\begin{array}{l}0.183 * * \\
(0.092)\end{array}$ \\
\hline \multicolumn{9}{|c|}{ Community Characteristics } \\
\hline $\begin{array}{l}\text { Total rainfall in } \\
\text { the previous } \\
\text { season (log) }\end{array}$ & $\begin{array}{l}1.069^{* * *} \\
(0.224)\end{array}$ & $\begin{array}{l}1.650^{* * *} \\
(0.289)\end{array}$ & $\begin{array}{c}0.073 \\
(0.185)\end{array}$ & $\begin{array}{l}-0.591 * * \\
(0.286)\end{array}$ & $\begin{array}{l}0.966^{* * *} \\
(0.224)\end{array}$ & $\begin{array}{c}0.295 \\
(0.220)\end{array}$ & $\begin{array}{l}-0.767^{* *} \\
(0.308)\end{array}$ & $\begin{array}{c}0.368^{* * *} \\
(0.142)\end{array}$ \\
\hline $\begin{array}{l}\text { Rainfall variability } \\
\text { in the previous } \\
\text { season }(\log )\end{array}$ & $\begin{array}{c}0.295 \\
(0.237)\end{array}$ & $\begin{array}{l}-0.230 \\
(0.274)\end{array}$ & $\begin{array}{l}0.554^{* * *} \\
(0.159)\end{array}$ & $\begin{array}{c}0.129 \\
(0.256)\end{array}$ & $\begin{array}{c}0.216 \\
(0.201)\end{array}$ & $\begin{array}{l}-0.272 \\
(0.208)\end{array}$ & $\begin{array}{l}1.679 * * * \\
(0.292)\end{array}$ & $\begin{array}{c}0.221 \\
(0.140)\end{array}$ \\
\hline Extension visits (log) & $\begin{array}{c}0.058 \\
(0.067)\end{array}$ & $\begin{array}{c}0.022 \\
(0.072)\end{array}$ & $\begin{array}{c}0.053 \\
(0.050)\end{array}$ & $\begin{array}{c}0.096 \\
(0.096)\end{array}$ & $\begin{array}{c}0.083 \\
(0.059)\end{array}$ & $\begin{array}{l}0.402 * * * \\
(0.061)\end{array}$ & $\begin{array}{l}0.267^{* *} \\
(0.109)\end{array}$ & $\begin{array}{c}0.018 \\
(0.040)\end{array}$ \\
\hline $\begin{array}{l}\text { Distance to } \\
\text { market (log) }\end{array}$ & $\begin{array}{l}-0.079 \\
(0.052)\end{array}$ & $\begin{array}{l}-0.023 \\
(0.061)\end{array}$ & $\begin{array}{c}0.009 \\
(0.040)\end{array}$ & $\begin{array}{c}0.034 \\
(0.065)\end{array}$ & $\begin{array}{c}-0.231^{* * *} \\
(0.049)\end{array}$ & $\begin{array}{c}0.003 \\
(0.049)\end{array}$ & $\begin{array}{l}-0.032 \\
(0.078)\end{array}$ & $\begin{array}{c}0.106 * * * \\
(0.032)\end{array}$ \\
\hline Year $(1=2018)$ & $\begin{array}{l}0.360^{* * *} \\
(0.065)\end{array}$ & $\begin{array}{l}0.236^{* * *} \\
(0.081)\end{array}$ & $\begin{array}{l}-0.064 \\
(0.050)\end{array}$ & $\begin{array}{l}0.712 * * * \\
(0.118)\end{array}$ & $\begin{array}{c}0.063 \\
(0.057)\end{array}$ & $\begin{array}{l}-0.296^{* * *} \\
(0.080)\end{array}$ & $\begin{array}{l}0.441^{* * *} \\
(0.111)\end{array}$ & $\begin{array}{c}-0.093^{* *} \\
(0.041)\end{array}$ \\
\hline Constant & $\begin{array}{c}-6.449 \\
* * * \\
(1.538)\end{array}$ & $\begin{array}{l}-9.897^{* * *} \\
(1.940)\end{array}$ & $\begin{array}{c}0.362 \\
(1.289)\end{array}$ & $\begin{array}{c}1.487 \\
(1.789)\end{array}$ & $\begin{array}{l}-7.110 * * * \\
(1.672)\end{array}$ & $\begin{array}{l}-4.011 \text { ** } \\
(1.571)\end{array}$ & $\begin{array}{l}7.051^{* * *} \\
(2.149)\end{array}$ & $\begin{array}{l}-3.133^{* * *} \\
(1.040)\end{array}$ \\
\hline $\begin{array}{c}\text { No. of } \\
\text { observations }\end{array}$ & 3914 & 3914 & 3914 & 3914 & 3914 & 3914 & 3914 & 3914 \\
\hline
\end{tabular}

Notes: All dependent variables are binary indicators. Robust clustered standard errors at the household level in parentheses. The result without the CRE framework is reported in Supplementary Table S1. Time averages for MC device and administrative dummies are also controlled for and showed in Supplementary Table S2. ${ }^{*} p<0.10,{ }^{* *} p<0.05,{ }^{* * *} p<0.01$.

- Field characteristics

Manure was more likely to be applied on owned fields, which could be related to tenure security reasons and the time it takes to reap the benefits from manure. Similar results were found in Ethiopia [3,41], Tanzania [4], and Kenya [29]. Fertilizer, improved varieties, herbicides, and erosion control were more likely to be used on larger maize fields. Larger fields may be prioritized for receiving purchased inputs such as fertilizer and improved maize varieties as they may be relatively strategic to the household in terms of food security and farm income. Moreover, households that cultivated larger fields could be better off in terms of access to external inputs [3]. Bedeke et al. [9] and Abate et al. [21] also found that farmers tended to use inorganic fertilizer and improved maize varieties on larger fields, respectively. Herbicides were also more likely to be used on larger maize fields, probably because of the high labor requirement of weeding on such fields [35]. The probability of using manure and practicing crop rotation was inversely associated with field size. Abera et al. and Nigussie et al. also found a negative association between manure and field size in Ethiopia [41,42]. Manure can be cost-effective to use on smaller fields compared to larger fields, and manure availability may also be limiting for larger fields. 
Distance from home was also associated with increased use of fertilizer, improved varieties, pesticides, and crop rotation. Fertilizer may be preferred for relatively distant fields as these fields may less likely receive organic fertilizer such as manure $[4,43]$. Indeed, manure (and intercropping) were less practiced on plots located further away from the homestead, as is also documented in other studies [44]. Pests and diseases are also more difficult to control manually when they occur further away from the homestead and pesticides may help in such conditions. The number of years since the field was acquired by the household was associated with an increased likelihood of manure use and erosion control. This can be related to the result found above on ownership, i.e., that farmers may apply manure and erosion control when they manage the field for a longer period of time (strategic management). Somewhat surprisingly, intercropping and crop rotation were less practiced on maize fields which had been managed by the farmer for longer periods of time.

\section{- Household characteristics}

Male-headed households were less likely to use herbicides compared to female-headed households. A similar result was found for Ethiopia [35], despite the cultural association of weeding with female labor in Ethiopia [35]. The association between education and management practices was mixed. Education was associated with an increased probability of using improved maize variety and erosion control, but also with a decreased likelihood of using pesticide, intercropping, and crop rotation, which is somewhat counter-intuitive. The positive association between using improved variety and education is in line with previous studies (e.g., [21]). The number of adults in the household was associated with an increased probability of applying manure, intercropping, and crop rotation. The number of adults is a proxy for labor availability, and more labor can facilitate manure management and intercropping as these practices require labor to implement [4,45]. Rusinamhodzi et al. [45] showed that intercropping needed more labor mainly due to increased weeding requirements. Livestock was positively related to the likelihood of using manure, which makes sense as a household's own livestock is the most common source of manure in Ethiopia [3]. The number of cultivated fields was negatively associated with the probability of using improved varieties and manure. This may be related to resource constraints, e.g., limited budget for seed or limited manure supply may restrict application to few fields. Crop rotation was more prevalent on farms with more fields implying that having many fields facilitates rotating crops.

\section{- Community characteristics}

Rainfall in the previous production season was associated with an increased probability of using fertilizer, improved varieties, herbicides, and crop rotation. This is in accordance with previous findings that input use decisions are often conditioned by previous season information (e.g., [11,46]). However, we find it difficult to explain the negative relationship between lagged rainfall and pesticide use and intercropping. Rainfall variability was positively associated with the likelihood of manure use. The reason may be that farmers minimize risk by using manure rather than buying external inputs (mineral fertilizer) when they expect production risks due to rainfall variability. Similar results were found in Tanzania [4], Kenya [29], and Ethiopia [47]. Rainfall variability also had a positive association with the likelihood of intercropping, possibly indicating that intercropping can serve as a risk mitigation strategy (a finding consistent with [4] in Tanzania). Herbicide was less likely to be used in more remote areas, perhaps reflecting transport and other transactions costs of accessing input markets and/or lower labor costs (and thus lower incentives for labor-saving technologies) in remote areas as documented in Tamru et al. [35]. Distance to market was positively associated with the use of crop rotations which could possibly be related to the relatively greater need of remote households to meet consumption objectives through diversified own-farm production (as opposed to the market). A similar result was found in another study for Ethiopia [47]. Extension visits were positively associated with intercropping and erosion control. 


\subsection{Explaining the Use of Management Packages}

Since most households in our sample used improved seed and fertilizer, we want to understand what accounts for the complementary management practices which we expect to influence the yield gap (Table 6). The complementary practices are manure, crop protection (pesticide and herbicide use), and integrated management options (intercropping, erosion control, crop rotation).

Table 6. Explaining the use of management packages.

\begin{tabular}{|c|c|c|c|c|c|c|c|}
\hline \multirow[b]{2}{*}{ Variables } & \multicolumn{7}{|c|}{ Management Packages } \\
\hline & Mgt2 & Mgt3 & Mgt4 & Mgt5 & Mgt6 & Mgt7 & Mgt8 \\
\hline \multicolumn{8}{|c|}{ Field Characteristics } \\
\hline Ownership of land (1 = owned $)$ & $\begin{array}{c}1.861 \\
(0.571)^{* * *}\end{array}$ & $\begin{array}{c}-0.494 \\
(0.262)^{* * *}\end{array}$ & $\begin{array}{l}-0.036 \\
(0.547)\end{array}$ & $\begin{array}{c}-0.48 \\
(0.293)\end{array}$ & $\begin{array}{c}0.708 \\
(0.543)\end{array}$ & $\begin{array}{c}-0.307 \\
(0.26)\end{array}$ & $\begin{array}{c}1 \\
(0.548)\end{array}$ \\
\hline Field size (log) & $\begin{array}{l}-1.059 \\
(0.697)\end{array}$ & $\begin{array}{l}-0.494 \\
(0.441)\end{array}$ & $\begin{array}{c}-1.446 \\
(0.833) *\end{array}$ & $\begin{array}{c}1.509 \\
(0.466)^{* * *}\end{array}$ & $\begin{array}{c}1.482 \\
(0.793)\end{array}$ & $\begin{array}{c}1.656 \\
(0.443)^{* * *}\end{array}$ & $\begin{array}{c}1.867 \\
(0.943)^{* *}\end{array}$ \\
\hline Distance from home (log) & $\begin{array}{c}-1.42 \\
(0.109)^{* * *}\end{array}$ & $\begin{array}{c}0.135 \\
(0.064)^{* *}\end{array}$ & $\begin{array}{c}-0.982 \\
(0.107)^{* * *}\end{array}$ & $\begin{array}{c}0.168 \\
(0.083)^{* *}\end{array}$ & $\begin{array}{c}-1.104 \\
(0.136)^{* * *}\end{array}$ & $\begin{array}{c}0.188 \\
(0.081)^{* *}\end{array}$ & $\begin{array}{c}-0.852 \\
(0.127)^{* * * *}\end{array}$ \\
\hline Number of years acquired (log) & $\begin{array}{l}0.462 \\
(0.36)\end{array}$ & $\begin{array}{l}-0.046 \\
(0.197)\end{array}$ & $\begin{array}{c}0.825 \\
(0.429)^{* *}\end{array}$ & $\begin{array}{c}0.168 \\
(0.215)\end{array}$ & $\begin{array}{l}-0.098 \\
(0.308)\end{array}$ & $\begin{array}{c}0.007 \\
(0.208)\end{array}$ & $\begin{array}{c}0.394 \\
(0.519)\end{array}$ \\
\hline \multicolumn{8}{|c|}{ Household Characteristics } \\
\hline Age (log) & $\begin{array}{l}-0.057 \\
(0.432)\end{array}$ & $\begin{array}{l}0.26 \\
(0.3)\end{array}$ & $\begin{array}{c}-0.136 \\
(0.441)\end{array}$ & $\begin{array}{c}0.325 \\
(0.405)\end{array}$ & $\begin{array}{l}-0.511 \\
(0.776)\end{array}$ & $\begin{array}{c}0.296 \\
(0.437)\end{array}$ & $\begin{array}{c}0.183 \\
(0.692)\end{array}$ \\
\hline Gender (1 = Male) & $\begin{array}{l}-0.174 \\
(0.432)\end{array}$ & $\begin{array}{l}-0.132 \\
(0.286)\end{array}$ & $\begin{array}{c}-0.45 \\
(0.546)\end{array}$ & $\begin{array}{c}0.011 \\
(0.451)\end{array}$ & $\begin{array}{l}-0.237 \\
(0.633)\end{array}$ & $\begin{array}{c}0.055 \\
(0.422)\end{array}$ & $\begin{array}{l}-0.366 \\
(0.566)\end{array}$ \\
\hline Education (log) & $\begin{array}{l}-0.008 \\
(0.111)\end{array}$ & $\begin{array}{l}-0.035 \\
(0.082)\end{array}$ & $\begin{array}{c}0.054 \\
(0.135)\end{array}$ & $\begin{array}{c}-0.236 \\
(0.12)^{* *}\end{array}$ & $\begin{array}{l}-0.197 \\
(0.163)\end{array}$ & $\begin{array}{c}-0.216 \\
(0.11)^{* *}\end{array}$ & $\begin{array}{l}-0.007 \\
(0.178)\end{array}$ \\
\hline Number of adults (log) & $\begin{array}{c}1.034 \\
(0.353)^{* * *}\end{array}$ & $\begin{array}{c}0.563 \\
(0.244)^{* *}\end{array}$ & $\begin{array}{c}0.491 \\
(0.396)\end{array}$ & $\begin{array}{l}-0.117 \\
(0.337)\end{array}$ & $\begin{array}{l}-0.203 \\
(0.641)\end{array}$ & $\begin{array}{c}0.166 \\
(0.313)\end{array}$ & $\begin{array}{c}0.19 \\
(0.495)\end{array}$ \\
\hline Asset value (log) & $\begin{array}{c}0.067 \\
(0.139)\end{array}$ & $\begin{array}{l}-0.038 \\
(0.095)\end{array}$ & $\begin{array}{c}0.167 \\
(0.154)\end{array}$ & $\begin{array}{c}0.208 \\
(0.132)\end{array}$ & $\begin{array}{c}0.332 \\
(0.181)\end{array}$ & $\begin{array}{c}0.097 \\
(0.127)\end{array}$ & $\begin{array}{c}0.554 \\
(0.193)^{* * *}\end{array}$ \\
\hline Livestock (log) & $\begin{array}{c}0.591 \\
(0.344)\end{array}$ & $\begin{array}{c}0.003 \\
(0.227)\end{array}$ & $\begin{array}{c}0.218 \\
(0.411)\end{array}$ & $\begin{array}{c}0.23 \\
(0.314)\end{array}$ & $\begin{array}{c}0.871 \\
(0.537)\end{array}$ & $\begin{array}{c}0.411 \\
(0.331)\end{array}$ & $\begin{array}{l}0.147 \\
(0.49)\end{array}$ \\
\hline Number of plots (log) & $\begin{array}{c}-1.035 \\
(0.338)^{* * *}\end{array}$ & $\begin{array}{c}0.235 \\
(0.253)\end{array}$ & $\begin{array}{c}0.189 \\
(0.412)\end{array}$ & $\begin{array}{c}0.329 \\
(0.348)\end{array}$ & $\begin{array}{l}0.403 \\
(0.49)\end{array}$ & $\begin{array}{c}0.554 \\
(0.337)\end{array}$ & $\begin{array}{c}0.327 \\
(0.492)\end{array}$ \\
\hline \multicolumn{8}{|c|}{ Community Characteristics } \\
\hline $\begin{array}{c}\text { Total rainfall in the previous } \\
\text { season (log) }\end{array}$ & $\begin{array}{c}0.606 \\
(1.133)\end{array}$ & $\begin{array}{c}0.172 \\
(0.631)\end{array}$ & $\begin{array}{l}-0.013 \\
(1.237)\end{array}$ & $\begin{array}{c}5.326 \\
(1.075)^{* * *}\end{array}$ & $\begin{array}{c}4.86 \\
(1.521)^{* * *}\end{array}$ & $\begin{array}{c}6.063 \\
(0.961)^{* * *}\end{array}$ & $\begin{array}{c}4.783 \\
(1.378)^{* * *}\end{array}$ \\
\hline $\begin{array}{l}\text { Rainfall variability in the previous } \\
\text { season (log) }\end{array}$ & $\begin{array}{l}-0.038 \\
(0.773)\end{array}$ & $\begin{array}{l}-0.89 \\
(0.548)\end{array}$ & $\begin{array}{c}0.428 \\
(0.991)\end{array}$ & $\begin{array}{l}-3.312 \\
(1.027) * * *\end{array}$ & $\begin{array}{l}-2.091 \\
(1.104) *\end{array}$ & $\begin{array}{l}-3.204 \\
(0.91)^{* * *}\end{array}$ & $\begin{array}{l}-1.434 \\
(1.077)\end{array}$ \\
\hline Number of extension visits (log) & $\begin{array}{c}0.348 \\
(0.155)^{* *}\end{array}$ & $\begin{array}{c}0.336 \\
(0.118)^{* * * *}\end{array}$ & $\begin{array}{c}0.475 \\
(0.171)^{* * * *}\end{array}$ & $\begin{array}{c}0.321 \\
(0.148)^{* *}\end{array}$ & $\begin{array}{c}0.363 \\
(0.212) *\end{array}$ & $\begin{array}{c}0.619 \\
(0.144)^{* * * *}\end{array}$ & $\begin{array}{c}0.597 \\
(0.222)^{* * *}\end{array}$ \\
\hline Distance to market (log) & $\begin{array}{l}-0.18 \\
(0.126)\end{array}$ & $\begin{array}{c}0.14 \\
(0.093)\end{array}$ & $\begin{array}{c}0.018 \\
(0.147)\end{array}$ & $\begin{array}{l}-0.186 \\
(0.11) *\end{array}$ & $\begin{array}{l}-0.193 \\
(0.163)\end{array}$ & $\begin{array}{l}-0.128 \\
(0.111)\end{array}$ & $\begin{array}{l}-0.179 \\
(0.179)\end{array}$ \\
\hline Year $(1=2018)$ & $\begin{array}{c}-0.038 \\
(0.182)\end{array}$ & $\begin{array}{c}-0.213 \\
(0.13)\end{array}$ & $\begin{array}{c}-0.547 \\
(0.204)^{* * *}\end{array}$ & $\begin{array}{c}0.026 \\
(0.187)\end{array}$ & $\begin{array}{c}-0.105 \\
(0.264)\end{array}$ & $\begin{array}{c}-0.344 \\
(0.163)\end{array}$ & $\begin{array}{c}0.171 \\
(0.282)\end{array}$ \\
\hline Constant & $\begin{array}{l}-3.495 \\
(7.507)\end{array}$ & $\begin{array}{c}-3.777 \\
(4.14)\end{array}$ & $\begin{array}{r}-1.15 \\
(7.969)\end{array}$ & $\begin{array}{c}-39.465 \\
(6.989)^{* * *}\end{array}$ & $\begin{array}{c}-29.853 \\
(10.254) \\
* * *\end{array}$ & $\begin{array}{c}-42.945 \\
(6.406)^{* * *}\end{array}$ & $\begin{array}{c}-33.618 \\
(8.873)^{* * *}\end{array}$ \\
\hline Number of Obs. & 3341 & 3341 & 3341 & 3341 & 3341 & 3341 & 3341 \\
\hline
\end{tabular}

Notes: The control group is the use of fertilizer and improved maize variety. Robust clustered standard errors at the household level in parentheses. The result without the CRE framework is reported in Supplementary Table S3. Time averages of time-varying variables (the MC device) and zonal administrative dummies at zone level are also controlled for and shown in Supplementary Table S4. ${ }^{*} p<0.10$, ${ }^{* *} p<0.05,{ }^{* * *} p<0.01$. 
- $\quad$ Fertilizer + improved variety + manure (Mgt2)

Manure was more likely to be used with fertilizer and improved variety when the number of adults and livestock increased, and on fields that were owned by households. On the other hand, manure was less likely to be combined with fertilizer and improved variety when the distance from home and the number of fields operated by the households were higher (Table 6). These results are similar to results from our analysis of factors influencing the use of manure (Table 5). Manure management is costly in terms of labor, time, and energy [32]. The positive association of extension visits with Mgt2 (this holds true for all the packages in our result) is also in line with the aim of the agricultural extension strategy of Ethiopia to promote input packages [48].

- $\quad$ Fertilizer + improved variety + integrated management (Mgt3)

Mgt3 is less prevalent on owned fields. This is contrary to what one would expect, and we find this hard to explain. Distance from home was positively related to using Mgt3. The number of household adults, a proxy for labor availability, increased the probability of using integrated management, which is plausible given the labor intensity of integrated management activities. More extension visits were associated with an increased probability of combining integrated management with fertilizer and improved varieties.

- $\quad$ Fertilizer + improved variety + manure + integrated management (Mgt4)

Field size and distance from home were negatively related with using Mgt4 implying that farmers are less likely to use manure and integrated management (together with fertilizer and improved variety) on larger and distant fields. This is consistent with the result we obtained on the factors determining the individual practices in Section 3.2. On the other hand, Mgt4 was more likely to be used on older fields (i.e., a greater number of years since the field was acquired) and by farmers with numerous extension visits. Households are more likely to have interest and invest in practices that pay off in the long term when they manage their fields for a longer period of time.

- $\quad$ Fertilizer + improved variety + crop protection (Mgt5)

Farmers were more likely to apply crop protection practices together with fertilizer and improved variety (Mgt5) when field size and the distance to maize fields increased. This could be to save time and labor on relatively larger and distant maize fields. Theriault et al. [32] also found that households used modern inputs on larger fields. The probability of using Mgt5 was lower for better-educated farmers. This could reflect greater (unobserved) participation in off-farm activities which may result in less time and attention available for farm management [49]. However, the reverse reasoning may also hold: crop protection practices (in particular herbicides) are labor saving and thus farmers that engage in off-farm activities might be assumed to use these more. Farmers were more likely to use Mgt5 when total rainfall in the previous season increased. Rainfall variability in the previous season decreased the likelihood of combining crop protection practices with fertilizer and maize variety. The same associations with total rainfall and rainfall variability were found for Mgt6, Mgt7, and Mgt8. This could indicate that farmers combine practices when they expect higher rainfall and it corresponds with results found for Ethiopia by others [7]. Distance to the nearest market decreased the probability of using Mgt5, which is most likely due to market-related costs that may discourage farmers from using purchased inputs, while at the same time, labor may be less expensive in more remote areas. More extension visits increased the probability of using crop protection compared to using only fertilizer and improved variety.

- $\quad$ Fertilizer + improved variety + crop protection + manure (Mgt6)

Field size, assets, total rainfall, and extension visits were positively associated with the use of Mgt6. Because field size and assets serve as resource endowment indicators, it makes sense that such indicators are associated with investment capacities implied by the adoption of these practices [50]. In addition, labor-saving technologies, such as agrochemicals, are relatively more important on larger fields, ceteris paribus. 
- Fertilizer + improved variety + crop protection + integrated management (Mgt7)

Similar to the results we found for Mgt5, field size, distance from home, total rainfall in the previous season, and extension visits increased the likelihood of using Mgt7, whereas education decreased the probability of using Mgt7. Field size was positively related to the packages that contained crop protection, which is also documented elsewhere [32]. Households can tend to combine crop protection with other practices to compensate for the labor requirement needed for weed management on larger fields.

- Fertilizer + improved variety + crop protection + manure + integrated management (Mgt8)

Farmers were more likely to use the full package (Mgt8) on larger and owned fields, but less likely to use Mgt8 on fields that were further from the homestead. Wealthier farmers were also more likely to use Mgt8. The number of extension visits was positively correlated with full package usage. Extension services have been suggested to be a key source of information that improved maize productivity in Ethiopia [16].

\subsection{Relating Management Practices to Yield and Labor Productivity}

In this section, we present the associations between the management packages and outcome variables: yield and labor productivity.

3.4.1. The Use of Fertilizer and Improved Varieties on $85 \%$ of the Maize Fields Leads to above Average Yields for SSA, but Further Yield Gains Are Not Trivial

As noted above, farmers combine fertilizer and improved varieties on $85 \%$ of the maize fields in our sample. A similar result was documented in [19] indicating that about $88 \%$ of maize-producing households in Ethiopia combined fertilizer and improved varieties, the highest share in SSA followed by Malawi (82\%). Even though the full potential of the practices affecting maize yield depends on their optimal use (for example, the amount of fertilizer applied, timing, spacing [51]), the high use percentage reflects the increasing use of management packages. Table 7 presents actual average maize yield and labor productivity for the eight management packages, and for the $15 \%$ that did not adopt fertilizer nor improved varieties. Mgt1 clearly resulted in higher yields than Mgt0. Yet, yields of all other management packages did not differ significantly from that of Mgt1 (Supplementary Table S5). Hence, while the use of more comprehensive management packages has documented potential to increase yields [1,17,52], our work indicates that using more comprehensive packages is not a guarantee for higher yields, potentially indicating agronomic complexities which our data is not able to explain.

Table 7. Management packages and mean values of outcome variables.

\begin{tabular}{|c|c|c|c|c|c|c|}
\hline $\begin{array}{l}\text { Management } \\
\text { Packages }\end{array}$ & $\begin{array}{c}\text { Fertilizer }+ \\
\text { Improved Variety }\end{array}$ & $\begin{array}{c}\text { Yield } \\
\text { Protecting } \\
\text { (Pesticide and/or } \\
\text { Herbicide) }\end{array}$ & Manure & $\begin{array}{c}\text { Integrated } \\
\text { Management } \\
\text { (Intercropping and/or } \\
\text { Erosion Control } \\
\text { and/or Crop Rotation) }\end{array}$ & $\begin{array}{l}\text { Average Maize } \\
\text { Yield (t/ha) }\end{array}$ & $\begin{array}{c}\text { Average Labor } \\
\text { Productivity } \\
\text { (kg of Maize/ } \\
\text { Person Day) }\end{array}$ \\
\hline Mgt0 & & & & & 2.6 & 63 \\
\hline Mgt1 & $\sqrt{ }$ & & & & 3.4 & 76 \\
\hline Mgt2 & $\sqrt{ }$ & & $\sqrt{ }$ & & 3.1 & 72 \\
\hline Mgt3 & $\sqrt{ }$ & & & $\sqrt{ }$ & 3.5 & 68 \\
\hline Mgt4 & $\sqrt{ }$ & & $\sqrt{ }$ & $\sqrt{ }$ & 3.3 & 64 \\
\hline Mgt5 & $\sqrt{ }$ & $\sqrt{ }$ & & & 3.7 & 113 \\
\hline Mgt6 & $\sqrt{ }$ & $\sqrt{ }$ & $\sqrt{ }$ & & 3.5 & 99 \\
\hline Mgt7 & $\sqrt{ }$ & $\sqrt{ }$ & & $\sqrt{ }$ & 3.7 & 104 \\
\hline Mgt8 & $\sqrt{ }$ & $\sqrt{ }$ & $\sqrt{ }$ & $\sqrt{ }$ & 3.3 & 81 \\
\hline
\end{tabular}




\subsubsection{Small Yield Gains from Crop Protection Practices, but Substantial Labor \\ Productivity Increases}

Presenting average values of outcome values (Table 7) can be misleading as it does not consider the fact that the use of technologies and practices can be endogenously determined $[7,11,38,53]$. The impacts of management packages on maize yield and labor productivity by controlling for observed and unobserved characteristics are estimated using the multinomial endogenous treatment effects (METE) model and presented in Table 8. Factor loadings ( $\lambda$ ) for Mgt5 and Mgt7 show the existence of negative selection bias, suggesting that unobserved characteristics that increased the likelihood of using the packages are associated with lower yields on farms using these packages. The METE model results indicate that maize yield was $10 \%$ higher when crop protection practices were combined with fertilizer and improved variety. This relatively small difference may partly be attributed to the fact that farmers substitute labor for herbicides to control weeds. In addition, the effect of pesticides may be small if pests/disease incidences were absent or limited. In our data, only $10 \%$ and $2 \%$ of households reported unexpected losses from diseases in 2017 and 2018, respectively. Similarly, unexpected losses from pests were reported by $6 \%$ and $11 \%$ of the households in 2017 and 2018, respectively.

Table 8. METE model results: percentage differences and significance of Mgt2-Mgt8 compared to Mgt1 (Fertilizer + improved variety) for maize yield and labor productivity.

\begin{tabular}{|c|c|c|}
\hline Management Packages & Maize Yield & Labor Productivity \\
\hline \multicolumn{3}{|l|}{ Treatment Effects } \\
\hline Fertilizer + Improved variety + Manure (Mgt2) & $-11 \%(0.058) *$ & $-7 \%(0.076)$ \\
\hline Fertilizer + Improved variety + Integrated management (Mgt3) & $-14 \%(0.123)$ & $-7 \%(0.061)$ \\
\hline Fertilizer + Improved variety + Manure + Integrated management (Mgt4) & $1 \%(0.058)$ & $-44 \%(0.083) * * *$ \\
\hline Fertilizer + Improved variety + Crop protection $(\mathrm{Mgt} 5)$ & $10 \%(0.047)^{* *}$ & $16 \%(0.079)^{* *}$ \\
\hline Fertilizer + Improved variety + Manure + Crop protection (Mgt6) & $-10 \%(0.061) *$ & $38 \%(0.155)^{* *}$ \\
\hline Fertilizer + Improved variety + Crop protection + Integrated management (Mgt7) & $22 \%(0.076)^{* * *}$ & $70 \%(0.065)^{* * *}$ \\
\hline $\begin{array}{c}\text { Fertilizer }+ \text { Improved variety }+ \text { Crop protection }+ \text { Manure + Integrated } \\
\text { management }(\mathrm{Mgt} 8)\end{array}$ & $1 \%(0.065)$ & $19 \%(0.097) * *$ \\
\hline \multicolumn{3}{|l|}{ Selection Terms $(\lambda)$} \\
\hline Fertilizer + Improved variety + Manure $($ Mgt2) & $0.05(0.052)$ & $0.01(0.043)$ \\
\hline Fertilizer + Improved variety + Integrated management (Mgt3) & $0.17(0.142)$ & $0.04(0.044)$ \\
\hline Fertilizer + Improved variety + Manure + Integrated management (Mgt4) & $-0.07(0.052)$ & $0.33(0.038)^{* * *}$ \\
\hline Fertilizer + Improved variety + Crop protection $(\mathrm{Mgt} 5)$ & $-0.08(0.048)$ * & $0.10(0.046) * *$ \\
\hline Fertilizer + Improved variety + Manure + Crop protection (Mgt6) & $0.09(0.049) *$ & $-0.31(0.075) * * *$ \\
\hline Fertilizer + Improved variety + Crop protection + Integrated management (Mgt7) & $-0.23(0.074)^{* * *}$ & $-0.57(0.081)^{* * *}$ \\
\hline $\begin{array}{c}\text { Fertilizer + Improved variety + Crop protection + Manure + Integrated } \\
\text { management }(\mathrm{Mgt} 8)\end{array}$ & $-0.04(0.056)$ & $-0.19(0.034) * * *$ \\
\hline Sample size & \multicolumn{2}{|c|}{3295} \\
\hline
\end{tabular}

The control group is maize fields that received only fertilizer and improved varieties. 500 simulation draws were used. Robust standard errors clustered at the household level in parentheses. ${ }^{*} p<0.10,{ }^{* *} p<0.05,{ }^{* * *} p<0.01$.

On average, the highest maize yield, as well as labor productivity, was found when fertilizer, improved variety, crop protection, and integrated management (Mgt7) were used jointly (Table 8$)$. The yield gain $(22 \%)$ shows that integrated management can be more effective when combined with crop protection practices as well as fertilizer and improved variety, than using it in isolation. Labor productivity increased by $70 \%$, which is substantial, and an incentive to use this package. On the other hand, the package without crop protection and with manure and integrated management (Mgt4) decreased labor productivity almost by half compared to using only fertilizer and improved variety. The management practices manure application, intercropping, and erosion control demand more labor, which can be a challenge to smallholders who already face labor scarcity [54]. 
3.4.3. In Optimal Situations, Integrated Management Contributes to Maize Yield, but in Our Sample Only When Used with Crop Protection Package

On average, integrated management did not show a significant yield advantage when combined with fertilizer and improved varieties (Mgt4). There may be several possible underlying reasons. First, the practices included in the integrated management group (e.g., crop rotation and soil erosion control) usually give yield returns after repeated use of these practices across multiple years; effects on yields in the years of the first application may not be evident [25,55-57]. Schmidt et al. [56] showed that sustainable land management practices needed to be maintained for a minimum of seven years to obtain a significant increase in the value of production. Thus, our observations may capture only part of the agronomic impact of these practices over time. Second, the integrated management options may not be managed well. For example, the expected yield benefits from intercropping depend on the type of the crop mix and whether it is relay intercropping or intercropping with simultaneous planting of two species. Third, practices may not be used in their best contexts in terms of field characteristics and production potential. This is evident from Tables 5 and 6, which show, for example, that integrated management was less likely to be used when land was owned. In addition, the METE model results in the lower part of Table 8 show that unobserved characteristics that increased the likelihood of using Mgt5 and Mgt7 are associated with relatively low yields for farmers who used Mgt5 and Mgt7, while these packages increased the yields.

\subsubsection{Quantity and Quality of Manure May Explain Its Negative Association with} Maize Yield

The management packages that contain manure (Mgt2, 4, 6, and 8) showed lower or equal maize yields relative to the control group (using only fertilizer and improved variety) (Table 8; Figure 1). One possible reason for this is manure quality, which we did not observe directly. If manure is characterized by a high $\mathrm{C} / \mathrm{N}$ ratio, it will result in immobilization [58]. Second, farmers may use relatively low amounts of inorganic fertilizer when they also apply manure. We only observe a binary indicator of manure usage in our data and cannot control for different application levels. However, our data shows lower nitrogen rates on fields receiving manure compared to fields not receiving manure, and fertilizer use and manure use were negatively associated (Table 4). Third, even though we cannot verify the quantity of manure used from our data, an oversupply of manure could also lead to diminishing returns. Figure 1 shows that the unconditional yield responses to nitrogen applications are no longer unambiguously positive on manured fields that received an inorganic nitrogen supply in excess of $\sim 250 \mathrm{~kg} / \mathrm{ha}$. As shown in Njoroge et al. [59], information on past manure applications helped to understand its impact and the uncertainty in yield response to fertilizer. Our survey data do not include previous years' application data and we cannot explore this directly.

\subsubsection{Farmers May Use the Management Practices but Not Optimally}

Looking at all the packages considered, we note that the average maize yield was always far from the water-limited yield potential that the farmers could theoretically achieve given their local climate and soil conditions. The average maize yield is only $23 \%$ of the average water-limited potential yield $[17,60,61]$. This can only be explained by the sub-optimal input use and implementation of the management practices. Technologies and practices do not bring the anticipated return if they are not well managed based on agronomic principles and targeted at specific conditions $[62,63]$. Our data showed that the average nitrogen level that farmers apply is increasing (about $98 \mathrm{~kg} \mathrm{~N} / \mathrm{ha}$ on fertilized maize fields in our data), but it is still below the agronomic optimum [64]. However, the current or even higher $\mathrm{N}$ rates will only be used efficiently, with low environmental losses, if combined with excellent management practices managing all growth defining, limiting, and reducing factors $[64,65]$. 
While optimal combinations of management practices have been observed to increase yields $[6,17,33,60]$, our data suggest that this is not always the case. Our results indicated that this was partly related to the conditions under which practices were applied, e.g., whether the land is owned or not or the distance of the field from the homestead. However, after controlling for such variables, we still find ambiguous effects of integrated management (Tables 7 and 8), which may indicate additional unobserved variation in factors of importance. In any case, it seems clear that blanket recommendations for technologies and management practices does not necessarily lead to improved performance [66], and sitespecific recommendations are essential for sustainable intensification in Ethiopia $[49,67,68]$.

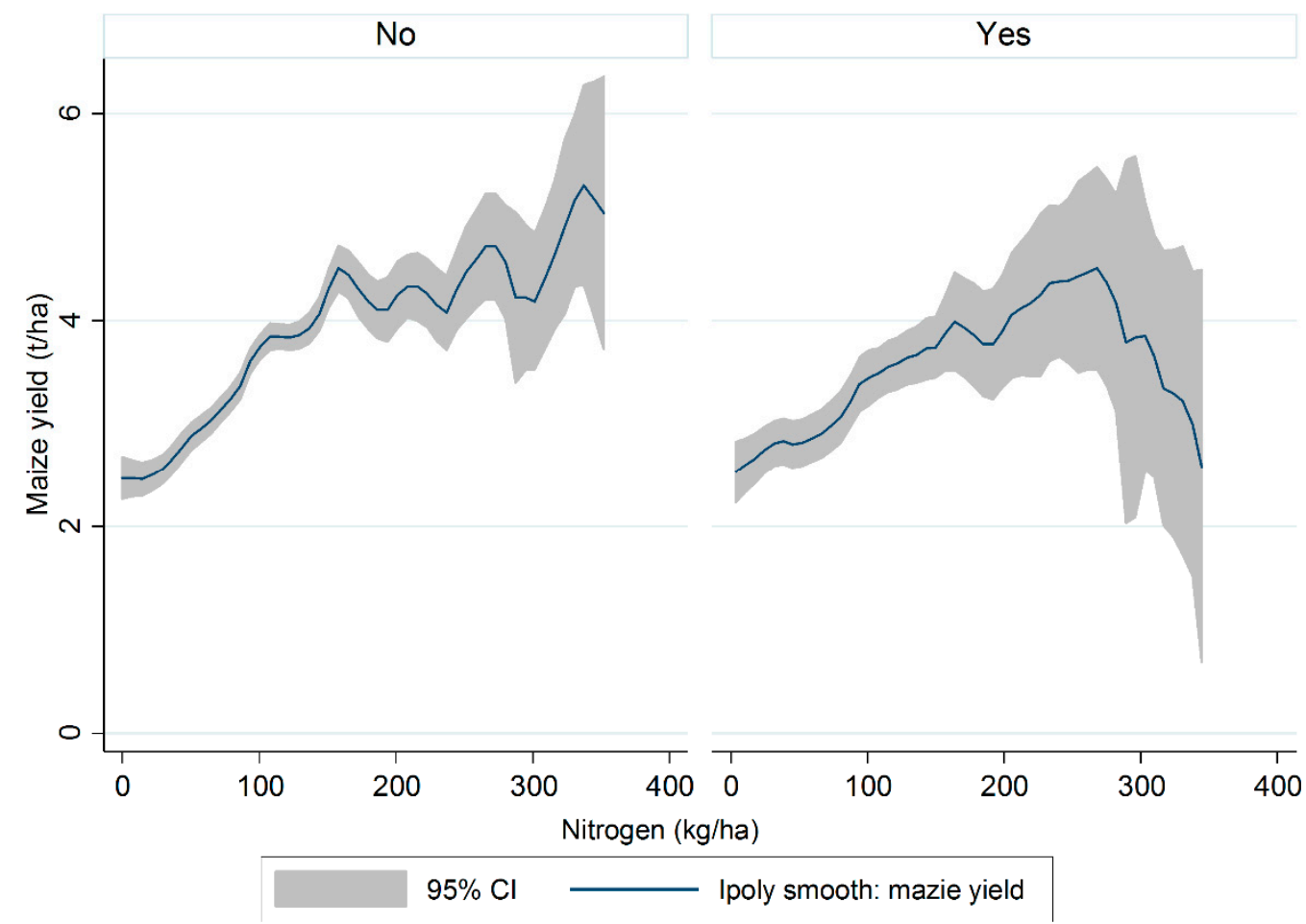

Figure 1. Maize yield in response to nitrogen fertilizer, without (No) and with (Yes) manure application. (Kernel-weighted local polynomial regression).

\subsection{Methodological Considerations}

We acknowledge that technology adoption is a process starting from awareness created amongst users, followed by evaluation, adoption, and revision/dis-adoption [69]. Our data did not allow us to evaluate technology use as a process. We were careful to avoid the use of the word "adoption" as adoption requires sustained use of management practices/technologies [55,70,71]. Using binary indicators to measure technology practices could mask variability in their intensity and effects. For example, we classified maize variety as local or improved, whereas improved varieties themselves vary in terms of productivity and costs [33]. Collecting data on the intensity and timing of the management practices could improve understanding of their use and effect. Moreover, a time series, preferably from the start of the adoption of management packages will give more insight. Future projects and studies should better target adoption dynamics to understand what influences decisions to adopt and dis-adopt, and to measure the influences of management practices that help to improve yield in the short and long term. Qualitative data could also augment quantitative analysis in understanding farmers' decisions and study its implication to outcomes. Farmer-reported information on management practices is often characterized by error and/or imprecision [72-74], and therefore combining methods may provide clearer insights. 
We also acknowledge that our estimations did not control for soil characteristics (data was not available for all fields), which could have implications for our results. Moreover, our examination of decisions made on maize fields may fail to integrate bigger picture management constraints or objectives which inform management outcomes [10,67]. For these reasons, some circumspection is warranted in the interpretation of our modeled treatment effects of different packages.

\section{Conclusions}

We considered a large set of management practices that were used in maize production and analyzed separate packages and combinations of packages using two years of data collected in 2017 and 2018 from two maize growing regions of Ethiopia. We showed that complementarity, as well as substitution effects, existed across individual management practices. The factors that explained the use of the technologies and practices differed across the practices investigated. For example, fertilizer, improved varieties, pesticides, and crop rotation were more often used in fields further away from home, while the use of manure and intercropping decreased with distance. Higher rainfall in the previous year was associated with increased use of fertilizer, improved varieties, herbicides, and crop rotation, while rainfall variability was correlated with increased manure and intercropping, suggesting differential practice preferences under different levels of production risk.

Farmers in our sample used both fertilizer and improved varieties on 85 percent of the maize fields, reflecting the success of Ethiopia's input promotion efforts over the last decade. However, combining fertilizer and improved varieties with other complementary inputs did not always lead to higher maize yield. Crop protection practices added only $10 \%$ to $22 \%$ (when integrated management was included) to yield. However, labor productivity impacts were higher (16-70\%) when crop protection practices were combined with any of the other packages, compared to using only fertilizer and improved varieties. Combining manure with inorganic fertilizer and improved variety showed lower maize yields, which was contrary to our expectations. Detailed information on the quality and quantity of manure could shed more light on the cause of this result. Using integrated management and manure in combination with fertilizer and improved variety (Mgt4) decreased labor productivity by half implying that these practices are labor demanding and interventions that target yield improvement need to evaluate the impacts on both labor demand and productivity.

The average maize yield achieved using different combinations of the management packages is far below the water-limited potential yield that can be achieved given local biophysical conditions. This suggests that farmers are not using the management practices optimally based on their specific contexts. Intensive study of the dynamics in time and precise implementation of the practices, together with experiments may help to better understand why the use of recommended technologies and management practices failed to narrow maize yield gaps.

Supplementary Materials: The following are available online at https://www.mdpi.com/article/10.3390/ agriculture11100938/s1, Tables S1-S5. Table S1: Multivariate probit estimates of individual management without CRE framework, Table S2: Multivariate probit estimates of individual management with CRE framework, Table S3: Multinomial logit estimates of management package decisions without CRE framework. The control group is use of fertilizer and improved maize variety, Table S4: Multinomial logit estimates of management package decisions with MC device and study zones. The control group is use of fertilizer and improved maize variety, Table S5: maize yield comparisons across the management packages.

Author Contributions: Conceptualization, B.T.A., J.C., P.R. and M.K.v.I.; methodology, B.T.A., J.C., P.R. and M.K.v.I.; formal analysis, B.T.A.; writing-original draft preparation, B.T.A.; writing-review and editing, B.T.A., J.C., P.R. and M.K.v.I.; supervision, J.C., P.R. and M.K.v.I. All authors have read and agreed to the published version of the manuscript. 
Funding: This research was funded by the Bill and Melinda Gates Foundation, through the Taking Maize Agronomy to Scale in Africa (TAMASA) project (grant no: OPP1113374) led by International Maize and Wheat Improvement Centre (CIMMYT). M.K.v.I. also acknowledges the NWO-WOTRO Strategic Partnership NL-CGIAR for funding.

Data Availability Statement: Not applicable.

Acknowledgments: We also kindly acknowledge support from the CGIAR Research Program MAIZE. M.K.v.I. thanks the NWO-WOTRO Strategic Partnership NL-CGIAR for funding. Data used in this analysis were collected in collaboration with the Ethiopian Institute of Agricultural Research (EIAR), under the TAMASA project.

Conflicts of Interest: The authors declare no conflict of interest.

\section{References}

1. Van Ittersum, M.K.; Van Bussel, L.G.; Wolf, J.; Grassini, P.; Van Wart, J.; Guilpart, N.; Claessens, L.; de Groot, H.; Wiebe, K.; Mason-D'Croz, D. Can sub-Saharan Africa feed itself? Proc. Natl. Acad. Sci. USA 2016, 113, 14964-14969. [CrossRef]

2. Takahashi, K.; Muraoka, R.; Otsuka, K. Technology adoption, impact, and extension in developing countries' agriculture: A review of the recent literature. Agric. Econ. 2019, 51, 31-45. [CrossRef]

3. Ahmed, M.H.; Geleta, K.M.; Tazeze, A.; Mesfin, H.M.; Tilahun, E.A. Cropping systems diversification, improved seed, manure and inorganic fertilizer adoption by maize producers of eastern Ethiopia. J. Econ. Struct. 2017, 6, 1-16. [CrossRef]

4. Kassie, M.; Jaleta, M.; Shiferaw, B.; Mmbando, F.; Mekuria, M. Adoption of interrelated sustainable agricultural practices in smallholder systems: Evidence from rural Tanzania. Technol. Forecast. Soc. Chang. 2013, 80, 525-540. [CrossRef]

5. Kassie, M.; Teklewold, H.; Marenya, P.; Jaleta, M.; Erenstein, O. Production Risks and Food Security under Alternative Technology Choices in Malawi: Application of a Multinomial Endogenous Switching Regression. J. Agric. Econ. 2015, 66, 640-659. [CrossRef]

6. Khonje, M.G.; Manda, J.; Mkandawire, P.; Tufa, A.H.; Alene, A.D. Adoption and welfare impacts of multiple agricultural technologies: Evidence from eastern Zambia. Agric. Econ. 2018, 49, 599-609. [CrossRef]

7. Marenya, P.P.; Gebremariam, G.; Jaleta, M.; Rahut, D.B. Sustainable intensification among smallholder maize farmers in Ethiopia: Adoption and impacts under rainfall and unobserved heterogeneity. Food Policy 2020, 95, 1-12. [CrossRef]

8. Oladimeji, T.E.; Oyinbo, O.; Hassan, A.A.; Yusuf, O. Understanding the Interdependence and Temporal Dynamics of Smallholders Adoption of Soil Conservation Practices Evidence from Nigeria. Sustainability 2020, 12, 2736. [CrossRef]

9. Bedeke, S.; Vanhove, W.; Gezahegn, M.; Natarajan, K.; Van Damme, P. Adoption of climate change adaptation strategies by maize-dependent smallholders in Ethiopia. NJAS-Wagening. J. Life Sci. 2019, 88, 96-104. [CrossRef]

10. Hörner, D.; Wollni, M. Integrated soil fertility management and household welfare in Ethiopia. Food Policy 2021, 100, 1-14. [CrossRef]

11. Manda, J.; Alene, A.D.; Gardebroek, C.; Menale, K.; Tembo, G. Adoption and impacts of sustainable agricultural practices on Maize Yields and Incomes-Evidence from Rural Zambia. J. Agric. Econ. 2016, 67, 130-153. [CrossRef]

12. Teklewold, H.; Kassie, M.; Shiferaw, B.; Köhlin, G. Cropping system diversification, conservation tillage and modern seed adoption in Ethiopia: Impacts on household income, agrochemical use and demand for labor. Ecol. Econ. 2013, 93, 85-93. [CrossRef]

13. de Janvry, A.; Sadoulet, E.; Suri, T. Field Experiments in Developing Country Agriculture. In Handbook of Economic Field Experiments; Banerjee, A.V., Duflo, E., Eds.; Elsevier: North Holland, The Netherlands, 2017; Volume 2, pp. 427-466.

14. Silva, J.V.; Reidsma, P.; Lourdes Velasco, M.; Laborte, A.G.; van Ittersum, M.K. Intensification of rice-based farming systems in Central Luzon, Philippines: Constraints at field, farm and regional levels. Agric. Syst. 2018, 165, 55-70. [CrossRef]

15. Vandercasteelen, J.; Dereje, M.; Minten, B.; Taffesse, A.S. Labour, profitability and gender impacts of adopting row planting in Ethiopia. Eur. Rev. Agric. Econ. 2018, 45, 471-503. [CrossRef]

16. Abate, T.; Shiferaw, B.; Menkir, A.; Wegary, D.; Kebede, Y.; Tesfaye, K.; Kassie, M.; Bogale, G.; Tadesse, B.; Keno, T. Factors that transformed maize productivity in Ethiopia. Food Secur. 2015, 7, 965-981. [CrossRef]

17. Assefa, B.T.; Chamberlin, J.; Reidsma, P.; Silva, J.V.; van Ittersum, M.K. Unravelling the variability and causes of smallholder maize yield gaps in Ethiopia. Food Secur. 2019, 12, 83-103. [CrossRef]

18. Binswanger-Mkhize, H.P.; Savastano, S. Agricultural intensification: The status in six African countries. Food Policy 2017, 67, 26-40. [CrossRef]

19. Sheahan, M.; Barrett, C.B. Ten striking facts about agricultural input use in Sub-Saharan Africa. Food Policy 2017, 67, 12-25. [CrossRef]

20. Assefa, B.T.; Reidsma, P.; Chamberlin, J.; van Ittersum, M.K. Farm- and community-level factors underlying the profitability of fertiliser for Ethiopian smallholder farmers. Forthcom. Agrekon 2021, in press.

21. Zeng, D.; Alwang, J.; Norton, G.W.; Shiferaw, B.; Jaleta, M.; Yirga, C. Ex postimpacts of improved maize varieties on poverty in rural Ethiopia. Agric. Econ. 2015, 46, 515-526. [CrossRef]

22. Abate, T.; Fisher, M.; Abdoulaye, T.; Kassie, G.T.; Lunduka, R.; Marenya, P.; Asnake, W. Characteristics of maize cultivars in Africa: How modern are they and how many do smallholder farmers grow? Agric. Food Secur. 2017, 6, 17. [CrossRef] 
23. Aune, J.B. The Prospects for Conservation Agriculture in Ethiopia. In Climate Impacts on Agricultural and Natural Resource Sustainability in Africa; Singh, B.R., Safalaoh, A., Amuri, N.A., Eik, L.O., Sitaula, B.K., Lal, R., Eds.; Springer International Publishing: Cham, Switzerland, 2020; pp. 23-39.

24. Baudron, F.; Thierfelder, C.; Nyagumbo, I.; Gérard, B. Where to Target Conservation Agriculture for African Smallholders? How to Overcome Challenges Associated with its Implementation? Experience from Eastern and Southern Africa. Environments 2015, 2, 338-357. [CrossRef]

25. Corbeels, M.; Naudin, K.; Whitbread, A.M.; Kühne, R.; Letourmy, P. Limits of conservation agriculture to overcome low crop yields in sub-Saharan Africa. Nat. Food 2020, 1, 447-454. [CrossRef]

26. Mulwa, C.; Marenya, P.; Rahut, D.B.; Kassie, M. Response to climate risks among smallholder farmers in Malawi: A multivariate probit assessment of the role of information, household demographics, and farm characteristics. Clim. Risk Manag. 2017, 16, 208-221. [CrossRef]

27. Teshome, H.; Tesfaye, K.; Dechassa, N.; Tana, T.; Huber, M. Smallholder Farmers' Perceptions of Climate Change and Adaptation Practices for Maize Production in Eastern Ethiopia. Sustainability 2021, 13, 9622. [CrossRef]

28. Biru, W.D.; Zeller, M.; Loos, T.K. The Impact of Agricultural Technologies on Poverty and Vulnerability of Smallholders in Ethiopia: A Panel Data Analysis. Soc. Indic. Res. 2020, 147, 517-544. [CrossRef]

29. Wainainaa, P.; Tongruksawattanab, S.; Qaim, M. Tradeoffs and complementarities in the adoption of improved seeds fertilizer and natural resource management technologies in Kenya. Agric. Econ. 2016, 47, 351-362. [CrossRef]

30. Teklewold, H.; Kassie, M.; Shiferaw, B. Adoption of Multiple Sustainable Agricultural Practices in Rural Ethiopia. J. Agric. Econ. 2013, 64, 597-623. [CrossRef]

31. Teklewold, H.; Mekonnen, A.; Kohlin, G. Climate change adaptation: A study of multiple climate-smart practices in the Nile Basin of Ethiopia. Clim. Dev. 2018, 11, 180-192. [CrossRef]

32. Theriault, V.; Smale, M.; Haider, H. How Does Gender Affect Sustainable Intensification of cereal production in the West African Sahel-evidence from Burkina faso? World Dev. 2016, 92, 177-191. [CrossRef]

33. Kassie, M.; Marenya, P.; Tessema, Y.; Jaleta, M.; Zeng, D.; Erenstein, O.; Rahut, D. Measuring Farm and Market Level economic impacts of improved maize production technologies in Ethiopia_evidence from panel data. J. Agric. Econ. 2018, 69, 76-95. [CrossRef]

34. Kassiea, M.; Teklewold, H.; Jaleta, M.; Marenyab, P.; Erensteinb, O. Understanding the adoption of a portfolio of sustainable intensification practices in eastern and southern Africa. Land Use Policy 2015, 42, 400-411. [CrossRef]

35. Tamru, S.; Minten, B.; Alemu, D.; Bachewe, F. The rapid expansion of herbicide use in smallholder agriculture in Ethiopia: Patterns, drivers, and implications. Eur. J. Dev. Res. 2017, 29, 628-647. [CrossRef]

36. Wooldridge, J.M. Eeconometric Analysis of Cross Section and Panel Data, 2nd ed.; MIT Press: Cambridge, London, UK, 2010.

37. Just, R.E.; Zilberman, D. Stochastic structure, farm size and technology adoption in developing agriculture. Oxf. Econ. Pap. 1983, 35, 307-328. [CrossRef]

38. Kim, J.; Mason, N.M.; Snapp, S.; Wu, F. Does sustainable intensification of maize production enhance child nutrition? Evidence from rural Tanzania. Agric. Econ. 2019, 50, 723-734. [CrossRef]

39. Deb, P.; Trivedi, P.K. Specification and simulated likelihood estimation of a non-normal treatment-outcome model with selection: Application to health care utilization. Econom. J. 2006, 9, 307-331. [CrossRef]

40. Ewunetu, A.; Simane, B.; Teferi, E.; Zaitchik, B.F. Relationships and the Determinants of Sustainable Land Management Technologies in North Gojjam Sub-Basin, Upper Blue Nile, Ethiopia. Sustainability 2021, 13, 6365. [CrossRef]

41. Nigussie, Z.; Tsunekawa, A.; Haregeweyn, N.; Adgo, E.; Nohmi, M.; Tsubo, M.; Aklog, D.; Meshesha, D.T.; Abele, S. Factors influencing small-scale farmers' adoption of sustainable land management technologies in north-western Ethiopia. Land Use Policy 2017, 67, 57-64. [CrossRef]

42. Abera, W.; Assen, M.; Budds, J. Determinants of agricultural land management practices among smallholder farmers in the Wanka watershed, northwestern highlands of EthiopiaI. Land Use Policy 2020, 99, 1-9. [CrossRef]

43. Vanlauwe, B.; Tittonell, P.; Mukalama, J. Within-farm soil fertility gradients affect response of maize to fertiliser application in western Kenya. Nutr. Cycl. Agroecosyst. 2006, 76, 171-182. [CrossRef]

44. Zerssa, G.; Feyssa, D.; Kim, D.-G.; Eichler-Löbermann, B. Challenges of Smallholder Farming in Ethiopia and Opportunities by Adopting Climate-Smart Agriculture. Agriculture 2021, 11, 192. [CrossRef]

45. Rusinamhodzi, L.; Corbeels, M.; Nyamangara, J.; Giller, K.E. Maize-grain legume intercropping is an attractive option for ecological intensification that reduces climatic risk for smallholder farmers in central Mozambique. Field Crops Res. 2012, 136, 12-22. [CrossRef]

46. Alem, Y.; Bezabih, M.; Kassie, M.; Zikhali, P. Does fertilizer use respond to rainfall variability? Panel data evidence from Ethiopia. Agric. Econ. 2010, 41, 165-175. [CrossRef]

47. Gebremariam, G.; Wondimagegn, T. The heterogeneous effect of shocks on agricultural innovations adoption_microeconometric evidence from rural Ethiopia. Food Policy 2018, 74, 154-161. [CrossRef]

48. Berhane, G.; Ragasa, C.; Abate, G.T.; Assefa, T.W. The State of Agricultural Extension Services in Ethiopia and Their Contribution to Agricultural Productivity; International Food Policy Research Institute; Ethiopian Development Research Institute: Addis Ababa, Ethiopia, 2018; pp. 1-29. 
49. Giller, K.E.; Andersson, J.A.; Corbeels, M.; Kirkegaard, J.; Mortensen, D.; Erenstein, O.; Vanlauwe, B. Beyond conservation agriculture. Front. Plant Sci. 2015, 6, 1-14. [CrossRef] [PubMed]

50. Vanlauwe, B.; Descheemaeker, K.; Giller, K.E.; Huising, J.; Merckx, R.; Nziguheba, G.; Wendt, J.; Zingore, S. Integrated soil fertility management in sub-Saharan Africa: Unravelling local adaptation. Soil 2015, 1, 491-508. [CrossRef]

51. Sime, G.; Aune, J. Sustainability of Improved Crop Varieties and Agricultural Practices: A Case Study in the Central Rift Valley of Ethiopia. Agriculture 2018, 8, 177. [CrossRef]

52. Desta, H.A. Effects of Organic and Inorganic Fertilizers on Selected Soil Properties after Harvesting Maize at Antra Catchment, Northwestern Ethiopia. Int. Invent. J. Agric. Soil Sci. 2015, 3, 68-78.

53. Di Falco, S.; Veronesi, M. How can African agriculture adapt to climate change? A counterfactual analysis from Ethiopia. Land Econ. 2013, 89, 743-766. [CrossRef]

54. Dahlin, A.S.; Rusinamhodzi, L. Yield and labor relations of sustainable intensification options for smallholder farmers in sub-Saharan Africa. A meta-analysis. Agron. Sustain. Dev. 2019, 39, 1-18. [CrossRef]

55. Bouwman, T.I.; Andersson, J.A.; Giller, K.E. Adapting yet not adopting? Conservation agriculture in Central Malawi. Agric. Ecosyst. Environ. 2021, 307, 1-14. [CrossRef]

56. Schmidt, E.; Chinowsky, P.; Robinson, S.; Strzepek, K. Determinants and impact of sustainable land management (SLM) investments: A systems evaluation in the Blue Nile Basin, Ethiopia. Agric. Econ. 2017, 48, 613-627. [CrossRef]

57. Liniger, H.; Studer, R.M.; Hauert, C.; Gurtner, M. Sustainable Land Management in Practice: Guidelines and Best Practices for SubSaharan Africa; World Overview of Conservation Approaches and Technologies (WOCAT); Food and Agriculture Organization of the United Nations (FAO): Rome, Italy, 2011; pp. 1-240.

58. Rufino, M.C. Quantifying the Contribution of Crop-Livestock Integration to African Farming. Ph.D. Thesis, Wageningen University and Research, Wageningen, The Netherlands, 2008.

59. Njoroge, S.; Schut, A.G.T.; Giller, K.E.; Zingore, S. Learning from the soil's memory: Tailoring of fertilizer application based on past manure applications increases fertilizer use efficiency and crop productivity on Kenyan smallholder farms. Eur. J. Agron. 2019, 105, 52-61. [CrossRef]

60. van Dijk, M.; Morley, T.; van Loon, M.; Reidsma, P.; Tesfaye, K.; van Ittersum, M.K. Reducing the maize yield gap in Ethiopia: Decomposition and policy simulation. Agric. Syst. 2020, 183, 1-11. [CrossRef]

61. Global Yield Gap Atlas. Available online: www.yieldgap.org/ethiopia (accessed on 17 March 2021).

62. Vanlauwe, B.; Coyne, D.; Gockowski, J.; Hauser, S.; Huising, J.; Masso, C.; Nziguheba, G.; Schut, M.; Van Asten, P. Sustainable intensification and the African smallholder farmer. Curr. Opin. Environ. Sustain. 2014, 8, 15-22. [CrossRef]

63. Vanlauwe, B.; Bationo, A.; Chianu, J.; Giller, K.E.; Merckx, R.; Mokwunye, U.; Ohiokpehai, O.; Pypers, P.; Tabo, R.; Shepherd, K.D. Integrated soil fertility management: Operational definition and consequences for implementation and dissemination. Outlook Agric. 2010, 39, 17-24. [CrossRef]

64. Ten Berge, H.F.; Hijbeek, R.; van Loon, M.P.; Rurinda, J.; Tesfaye, K.; Zingore, S.; Craufurd, P.; van Heerwaarden, J.; Brentrup, F.; Schröder, J.J. Maize crop nutrient input requirements for food security in sub-Saharan Africa. Glob. Food Secur. 2019, 23, 9-21. [CrossRef]

65. Van Ittersum, M.K.; Cassman, K.G.; Grassini, P.; Wolf, J.; Tittonell, P.; Hochman, Z. Yield gap analysis with local to global relevance-a review. Field Crop. Res. 2013, 143, 4-17. [CrossRef]

66. Silva, J.V.; Ramisch, J.J. Whose gap counts? The role of yield gap analysis within a development-oriented agronomy. Exp. Agric. 2019, 55, 311-338. [CrossRef]

67. Giller, K.E.; Tittonell, P.; Rufino, M.C.; Van Wijk, M.T.; Zingore, S.; Mapfumo, P.; Adjei-Nsiah, S.; Herrero, M.; Chikowo, R.; Corbeels, M. Communicating complexity: Integrated assessment of trade-offs concerning soil fertility management within African farming systems to support innovation and development. Agric. Syst. 2011, 104, 191-203. [CrossRef]

68. Kenea, W.B.; Reidsma, P.; Descheemaeker, K.; Rurinda, J.; Balemi, T.; van Ittersum, M.K. Variability in yield responses, physiological use efficiencies and recovery fractions of fertilizer use in maize in Ethiopia. Eur. J. Agron. 2021, 124, 1-12. [CrossRef]

69. Weersink, A.; Fulton, M. Limits to Profit Maximization as a Guide to Behavior Change. Appl. Econ. Perspect. Policy 2020, 42, 67-79. [CrossRef]

70. Glover, D.; Sumberg, J.; Andersson, J. The adoption problem; or why we still understand so little about technological change in African agriculture. Outlook Agric. 2016, 45, 3-6. [CrossRef]

71. Glover, D.; Sumberg, J.; Ton, G.; Andersson, J.; Badstue, L.O. Rethinking technological change in smallholder agriculture. Outlook Agric. 2019, 48, 169-180. [CrossRef]

72. Abay, K.A. Measurement errors in agricultural data and their implications on marginal returns to modern agricultural inputs. Agric. Econ. 2020, 51, 323-341. [CrossRef]

73. Abay, K.; Assfaw, T.; Chamberlin, J. Are smallholder efficiency estimates systematically biased by mismeasurement in farm survey data? Evidence from Ethiopia and Nigeria. Forthcom. Am. J. Agric. Econ. 2021, in press.

74. Wollburg, P.; Tiberti, M.; Zezza, A. Recall length and measurement error in agricultural surveys. Food Policy 2021, 100, 1-14. [CrossRef] 